\title{
Genetic diversity of Great Cormorants Phalacrocorax carbo in the eastern Baltic region
}

\section{Dalius Butkauskas ${ }^{1}$,}

Kristina Chaika ${ }^{2}$,

Saulius Švažas ${ }^{1}$,

Gennady Grishanov²,

Algimantas Paulauskas ${ }^{3}$,

\section{Žilvinas Pūtys ${ }^{1}$}

${ }^{1}$ Nature Research Centre, Akademijos St. 2, LT-08412

Vilnius, Lithuania

${ }^{2}$ Immanuel Kant Baltic

Federal University of Russia,

Universitetskaya St. 2,

236038 Kaliningrad, Russia

${ }^{3}$ Vytautas Magnus University, Vileikos St. 8, LT-44404

Kaunas, Lithuania
A rapid expansion of the continental subspecies of the Great Cormorant (Phalacrocorax carbo sinensis) has been recorded in Europe since the 1980s. Evaluation of genetic variability of the Great Cormorant using molecular markers is necessary for investigation of the mechanisms of formation of the newly established breeding populations in the eastern Baltic region (in the Kaliningrad region of Russia and in Lithuania). The samples for molecular investigation were collected in the largest breeding colonies of Great Cormorants located on the coast of the Curonian Lagoon of the Baltic Sea and in their smaller, later formed breeding colonies located in the continental part of Lithuania. After sequencing and alignment of partial fragments of mtDNA control region, 21 different haplotypes, including 8 new haplotypes never identified before, and 13 haplotypes described earlier were found. They were distributed with different frequency in different sampling sites. The haplotype network constructed using 342 bp D-loop sequences identified during the current study and all available sequences of Great Cormorants deposited in GenBank by previous investigators revealed haplotypes attributed to subspecies $P$. c. sinensis being distinguished from haplotypes of subspecies $P$. c. carbo in the separate part of haplotype network. The newly described haplotypes did not form a phylogenetically uniform group indicating possible colonization of the Kaliningrad region and the continental part of Lithuania by individuals descending from the largest breeding colonies spread at the coast zone of the Baltic Sea. A high level of genetic population diversity in different breeding colonies recorded in the Kaliningrad region and in eastern Lithuania confirms the formation of a highly variable and well-adapted population of the Great Cormorant participating in the process of colonization of new breeding areas in the Baltic region.

Keywords: mtDNA, D-loop, Phalacrocorax carbo sinensis, variability of haplotypes, genetic structure

\footnotetext{
*Corresponding author. E-mail: dalius@ekoi.lt
} 


\section{INTRODUCTION}

Two subspecies of the Great Cormorant are recognized in Europe: the Atlantic subspecies Phalacrocorax carbo carbo in the British Isles and Norway, and the continental subspecies Phalacrocorax carbo sinensis across Continental Europe (Winney et al., 2001). The Atlantic subspecies is estimated at about 42,500 breeding pairs, while the continental subspecies - at about 371,000 pairs. The Baltic Sea region is the key breeding area of the continental subspecies of the Great Cormorant with the total estimated population of about 167,700 pairs. The Kaliningrad region holds more than 9,500 pairs, while Lithuania - about 6,000 pairs. A marked increase of the breeding population was recorded in the Baltic region during the last decades (Bregnballe et al., 2014).

The first reports of Great Cormorants breeding in the Kaliningrad region are from 1985, when 30 nests were found in a colony on the southeastern coast of the Curonian Lagoon, at the estuary of the Deyma River. The numbers of nesting birds in this colony increased to 700 breeding pairs in 1993 (Grishanov, Romanov, 2007) and reached 8,500 pairs in 2005. In 2012, there were 9,535 breeding pairs of Great Cormorants in two colonies located on the southern coast of the Curonian Lagoon (Grishanov et al., 2014). 9,075 nests (representing 95\% of the total number of nests in the region) were counted in the largest breeding colony and 460 nests in a smaller colony in 2012. At present, the total population of the Great Cormorant in the Kaliningrad region is estimated at about 10,000 breeding pairs and up to 3,000 non-breeding individuals.

In Lithuania, the first breeding pair of the Great Cormorant was recorded in 1985. The breeding population in Lithuania in 1988 was estimated at $20-50$ pairs (Žydelis et al., 2002). During the initial period of formation of a new colony the number of nests of Great Cormorants increased from 3 in 1989 to 600 in 1995 (Švažas et al., 2011). In 2012, the total breeding population of the Great Cormorant in Lithuania was estimated at about 3,200 pairs, and in 2014 - at about 6,000 pairs. The largest colony was located on the Curonian Spit (the Baltic Sea coast), with 3,842 nests (64\% of the total breeding population) counted in 2014 . The second largest colony in Lithuania was located on the eastern coast of the Curonian Lagoon (at the estuary of the Skirvite River), with 674 nests counted in 2014 (Dagys, Zarankaite, 2014). The remaining five colonies ranging from 60 to 200 nests in size and established only during the recent decades were located in central and eastern Lithuania.

Earlier studies of genetic diversity of the Great Cormorant revealed 19 different haplotypes of control region characteristic of Phalacrocorax $c$. sinensis subspecies, 14 haplotypes representing $P$. c. carbo, and 5 intermediate haplotypes - subspecies P. c. norvegicus (Marion, Le Gentil, 2006).

The aim of this study was to define the genetic population structure of the newly established breeding colonies of the Great Cormorant in the eastern Baltic region and, using mtDNA methods, to determine possible phylogenetic relationships between different colonies.

\section{MATERIALS AND METHODS}

\section{Sample collection}

Twenty-eight specimens (muscle and liver tissues) were collected for genetic analysis from individuals of the known origin (young birds found dead in the colonies) in three breeding colonies located in the continental and coastal parts of Lithuania and on the southeastern coast of the Curonian Lagoon in the Deyma River estuary in the Kaliningrad region of Russia (Fig. 1). Ten specimens were collected from individuals of unknown origin (feeding birds hunted in two large fishpond complexes in Lithuania). All tissue samples were collected in 2013.

\section{DNA extraction, amplification, and sequencing}

Collected tissue samples were stored in ethanol in the fridge (at $-20^{\circ} \mathrm{C}$ ). DNA was prepared from tissue using salt-extraction method after digestion by Protenase $\mathrm{K}$, isopropanol extraction and subsequent precipitation following 


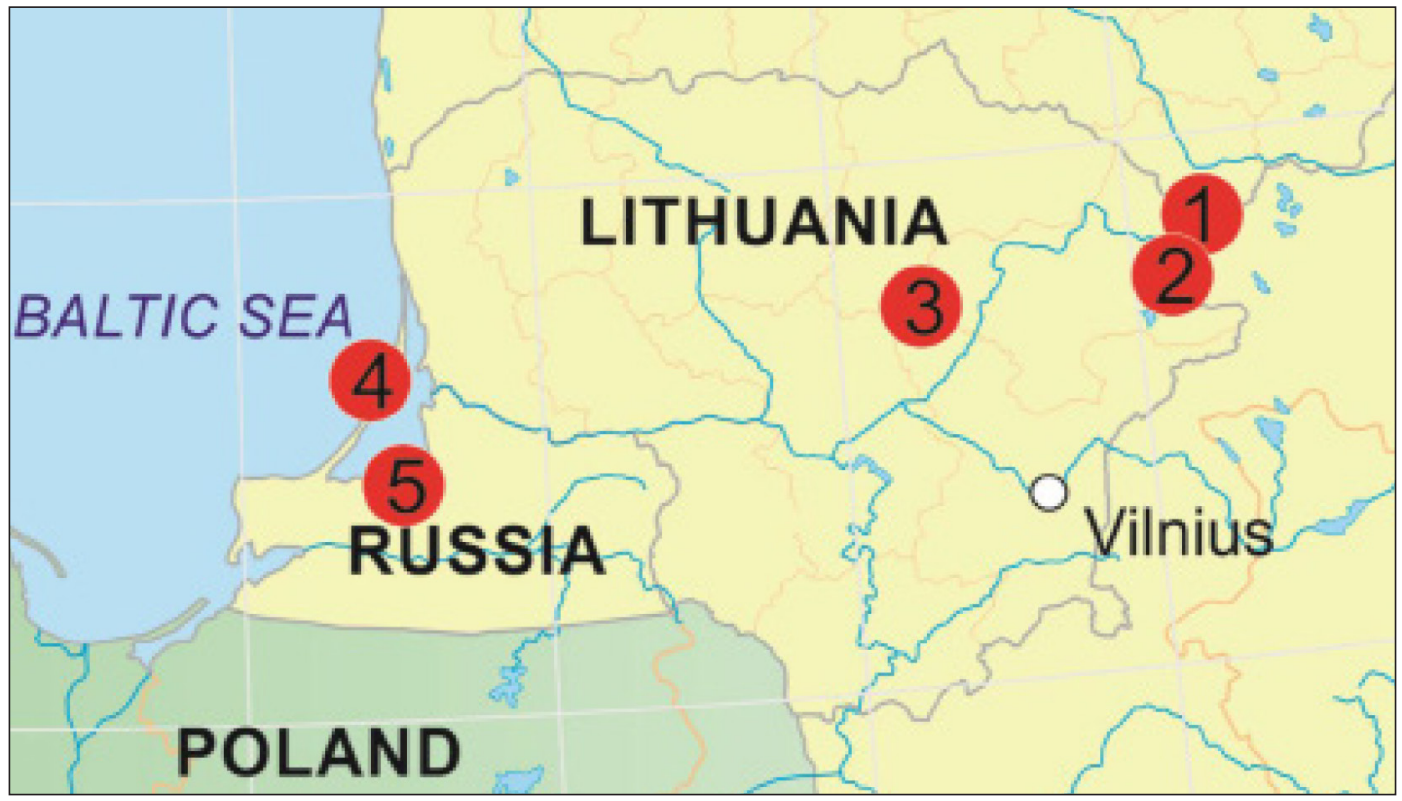

Fig. 1. Sampling sites of the Great Cormorant

1 - breeding colony at Lake Drūkšiai $(\mathrm{N}=10) ; 2$ - feeding site in Birveta fishponds $(\mathrm{N}=5)$;

3 - feeding site in Kapliai fishponds $(\mathrm{N}=5) ; 4$ - breeding colony at Juodkrante $(\mathrm{N}=1) ; 5$ - breed-

ing colony at the estuary of the Deyma River estuary $(\mathrm{N}=17)$.

Aljanabi and Martinez (1997) and amplified by polymerase chain reaction (PCR) with forward Pcarb-F 5'-TGTTCTCAACTACGGGAACTCA-3' and reverse Pcarb-R 5'-GTGAGGTGGACGATCAATAAA-3' primers specific to the control region (D-Loop).

A 434-bp DNA fragments of control region were amplified in the $25 \mu \mathrm{PCR}$ volume for each specimen consisting of $1 \times$ PCR buffer (with $50 \mathrm{mM} \mathrm{KCl}$ ), $0.2 \mathrm{mM}$ dNTP, $0.2 \mu \mathrm{M}$ of each primer, $2.5 \mathrm{mM} \mathrm{MgCl}$, $0.75 \mathrm{U}$ Taq DNA polymerase LC (MBI Fermentas), and 0.04$0.06 \mu \mathrm{g}$ template DNA.

Amplification started with an initial denaturation step for $5 \mathrm{~min}$ at $95^{\circ} \mathrm{C}$, followed by $30 \mathrm{cy}$ cles of denaturation for $45 \mathrm{~s}$ at $95^{\circ} \mathrm{C}$, annealing for $45 \mathrm{~s}$ at $59^{\circ} \mathrm{C}$, elongation for $1 \mathrm{~min}$ at $72^{\circ} \mathrm{C}$, and ended with a final elongation step for $10 \mathrm{~min}$ at $72{ }^{\circ} \mathrm{C}$. Purified PCR products and the same primers Pcarb-F and Pcarb-R were used for DNA sequencing at the Laboratory of Molecular Ecology of the Nature Research Centre using Big-Dye Terminator v3.1 Cycle Sequencing Kit (Applied Biosystems, USA) and 3500 Genetic Analyzer (Applied Biosystems, USA).
Newly obtained 37 mtDNA sequences of the control region were used for identification of different haplotypes characteristic of individuals collected in different sites during this study. Additional 49 sequences of control region deposited in the GenBank by the previous researchers Winney et al. $(1998,2001)$, GENBANK accession numbers: AF101172-AF101193); Marion, Le Gentil (2006), GENBANK accession numbers: AF101172-AF101193, AY684305-AY684327 and AY676597-AY676601) were included into our analysis of phylogenetic relationships of different haplotypes. All sequences were aligned using ClustalW algorithm (Thompson et al. 1994) implemented in MEGA6 (Tamura et al., 2013) program. Maximum likelihood (ML) tree of haplotypes of Great cormorants based on 342 bp fragments of control region was constructed using MEGA6 (Tamura et al., 2013).

The Median-joining haplotype network based on the same D-loop sequences of Great Cormorants was constructed using Phylogenetic Network Analysis Software (Network NETWORK version 4.6.1.4 available at www. fluxus-engineering.com). 
DNASP 4.10 (Rozas et al., 2003) was used to determine the number of haplotypes $h$, haplotype diversity parameters $\mathrm{Hd}$ and $K_{x y}$ distances, indicating the divergence between groups of sequences as measured by the uncorrected average number of nucleotide substitutions per site between populations (Nei, 1987). The obtained pairwise distances between populations $K_{x y}$ were used for a neighbour joining (NJ) analysis in MEGA 6.

\section{RESULTS}

DNA sequencing enabled identification of up to $342 \mathrm{bp}$ of the mtDNA control region. 21 different haplotypes were detected in samples of 37 Great Cormorants collected during this study, based on the alignment of partial fragments of the mtDNA control region. Among them, there were 8 new haplotypes never identified in earlier studies. The whole complex of newly-identified and earlier described haplotypes representing genetic diversity characteristic of the Great Cormorant is based on variations in 35 variable sites detectable in the indicated fragment of the mtDNA control region. It was used for further reconstruction of intra-specific phylogenetic relationships of Great Cormorant.

The maximum likelihood (ML) tree inferred from D-loop fragments deposited in GenBank and homologous sequences obtained during this study revealed relationships between the newly identified and earlier described haplotypes characteristic of subspecies Phalacrocorax carbo sinensis and Phalacrocorax c. carbo (Fig. 2). Haplotypes characteristic of subspecies P.c. carbo $(9,14,16-19,26,36-37,39-42)$ were indicated in the phylogenetic tree separately from other 43 haplotypes forming the cluster of more closely related branches, including sequences characteristic of subspecies P.c. sinensis (Fig. 2).

The established positions of unique haplotypes on the top of different branches of the haplotype network and their identification in each studied colony indicate a rapid evolutionary process characteristic of individuals participating in the process of colonization of new territories located at boundaries of the distribution range (Fig. 3).

The neighbour joining tree indicating genetic differences between colonies and samples of Great Cormorants collected in different sites was constructed using $K_{x y}$ distances. The genetic population structure of individuals sampled in their breeding colonies (located on the coast of the Curonian Lagoon in the Kaliningrad region and in eastern Lithuania) was rather similar but different from that of birds of unknown origin sampled in their feeding sites located in large fishponds of Lithuania in autumn (Fig. 4). It is likely that individuals sampled in fishponds were migrants from Northern Europe.

The comparison of the results of this study with those given by Winney et al. (1998, 2001; GenBank accession numbers: AF101172AF101193) has revealed that 5 haplotypes of Great Cormorants were found only among birds sampled in Lithuania, 2 - only among birds sampled in the Kaliningrad region and Kapliai fishponds, respectively, while 13 haplotypes were also characteristic of birds nesting in Continental Europe (Fig. 3). Four identical haplotypes were found among birds sampled in the breeding colonies located on the coast of the Curonian Lagoon in the Kaliningrad region and in eastern Lithuania.

\section{DISCUSSION}

A marked eastward and northward breeding range expansion of the Great Cormorant has been observed in Europe since the 1970s (Hagemeijer, Blair, 1997), with new breeding colonies established in all countries of the Baltic Sea region (Švažas et al., 2011). A very rapid increase in the numbers of Great Cormorants in Europe since the 1980s was mainly caused by improved protection measures in the countries of the European Union and by increased eutrophication of shallow coastal and inland waters (De Nie 1995; Van Eerden \& Gregersen 1995).

The newly-established breeding colonies in the Baltic countries and the Kaliningrad region of Russia were probably formed by individuals 


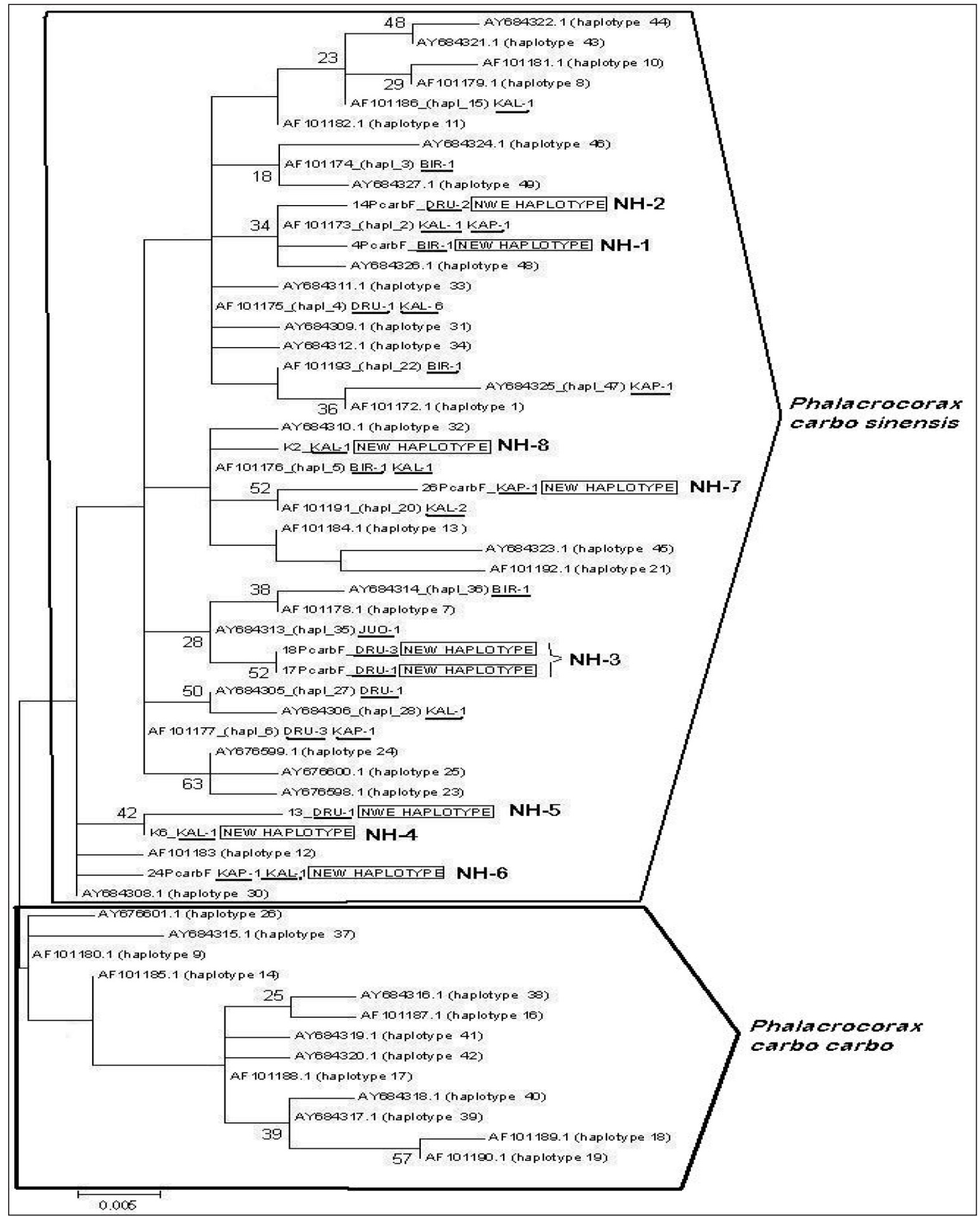

Fig. 2. The maximum likelihood (ML) tree of the haplotypes of Great Cormorants based on $342 \mathrm{bp}$ fragments of the control region

Bootstrap values at relevant nodes are shown. Haplotypes described by previous investigators are indicated according to the GenBank access number (the haplotype number is written in parentheses). The abbreviation of the sampling locality (Lake Drūkšiai - DRU, Kapliai - KAP, Birveta - BIR, Juodkranté - JUO, the Deyma River estuary - KAL) and the number of identical haplotypes detected during this study are underlined, new haplotypes are indicated as $\mathrm{NH}_{-}^{*}$ 


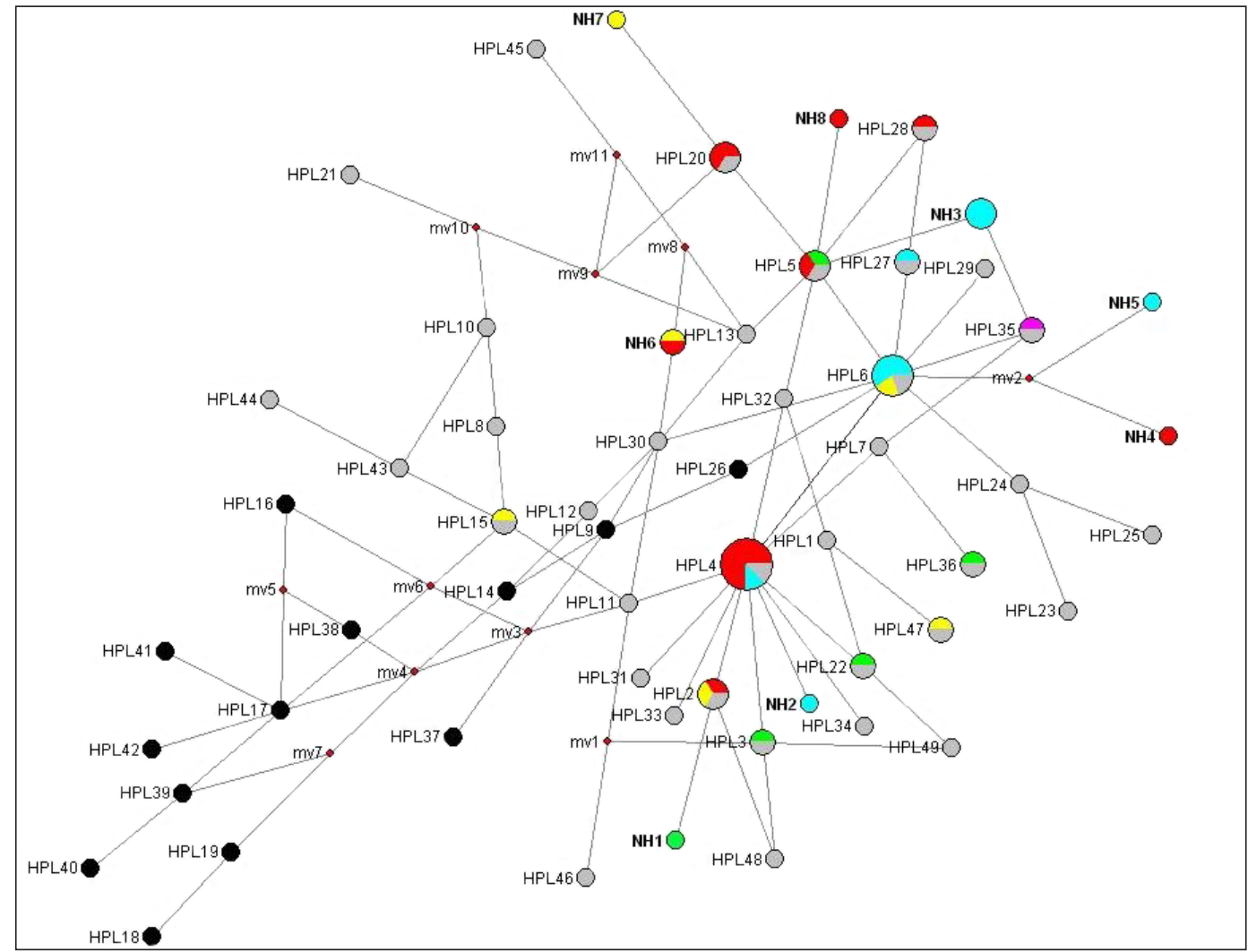

Fig. 3. Median-joining haplotype network based on D-loop sequences of the Great Cormorant The circle area is proportional to haplotype frequency; small circles (positions $\mathrm{mv}^{\star}$ ) indicate inferred intermediate haplotypes, the connecting lines correspond to the single substitution, except two substitutions existing between haplotypes indicated as NH7 and HPL20; unique haplotypes are named $\mathrm{NH}^{*}$ and are indicated in bold. Black colour indicates haplotypes attributed to subspecies Phalacrocorax c. carbo and grey colour - those attributed to subspecies Phalacrocorax c. sinensis; red colour indicates haplotypes found in individuals from the Deyma estuary colony; blue - haplotypes found in individuals in Lake Drūkšiai colony; yellow - haplotypes found in individuals of unknown origin in Kapliai fishponds; green - haplotypes found in individuals of unknown origin in Birveta fishponds; pink - the haplotype found in Juodkrantè colony.

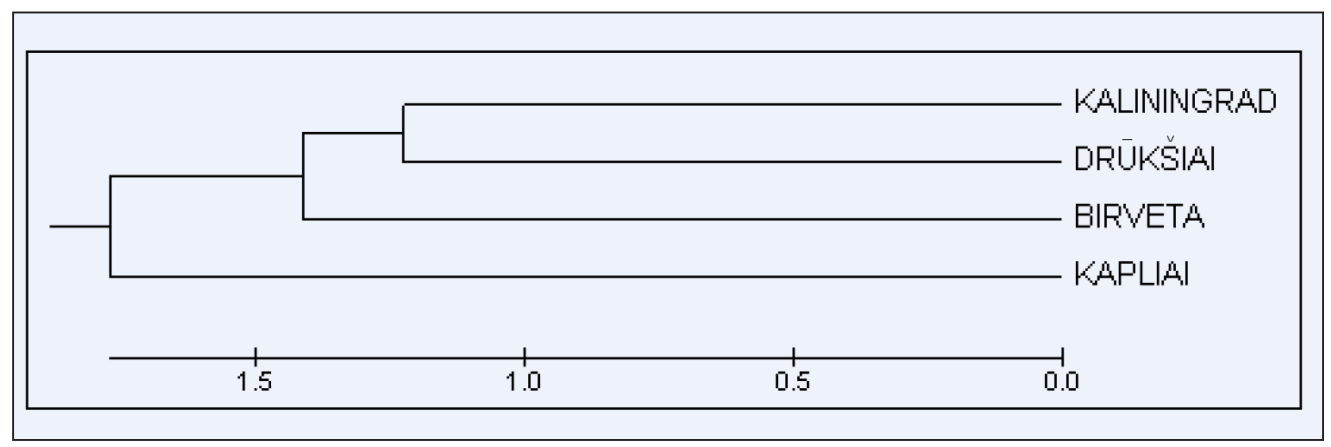

Fig. 4. The neighbour joining the phylogenetic tree indicating relationships between Great Cormorants sampled in different sites in Lithuania and in the Kaliningrad region (based on $K_{x y}$ distances and calculated using DnaSP version 5.10.01; Rozas et al. 2010) 
from the rapidly increasing Central European population of the continental subspecies, particularly from large breeding colonies located on the Polish coast of the Baltic Sea (Przybysz et al., 1988; Lindell et al., 1995). First colonies were formed in places of the former known breeding sites located on the coast of the Baltic Sea and abandoned in the 19th century (Švažas et al., 2011). Only certain newly-established small breeding colonies have developed into huge colonies holding more than several thousands of breeding individuals.

A rather similar genetic structure of the population defined for Great Cormorants breeding in the largest colony located on the coast of the Curonian Lagoon and in the newly-established small colonies in eastern Lithuania (located about $400 \mathrm{~km}$ eastwards) indicate that new breeding colonies were formed mostly by individuals from the expanding colonies earlier established in the eastern Baltic region, but not exclusively by birds breeding in coastal sites.

A relatively high genetic diversity of the population detected among studied individuals from the breeding colonies of Great Cormorants in Lithuania and the Kaliningrad region could be explained by immigration of birds of different origin. The diversity of the genetic structure of the population of new breeding colonies of Great Cormorants is similar to that of the expanding population of the Tufted Duck (Aythya fuligula) and of the recovering population of the White-tailed Eagle (Haliaeetus albicilla) described recently in the eastern Baltic region (Tubelyte et al., 2011; Treinys et al., 2016).

The differences of haplotype diversity detected in the studied colonies indicate that the expansion of the breeding range of the Great Cormorant and the formation of new colonies in the eastern Baltic region occurred simultaneously from different areas presumably located on the coast of the Baltic Sea contributing to the fitness and increased adaptation of the newly established breeding colonies.

The current study did not reveal any evidence of some level of introgression/hybridization between different subspecies of the Great Cormorant in the Baltic Sea region despite rapid expantion of the P.c. sinensis population and broken down geographical isolating mechanisms (Goostrey et al., 1998). The success of range expansion of the population of the Great Cormorant depends on high genetic variability that correlates positively with population fitness and can increase possibilities of adaptations of the species in new environment (Reed, Frankham, 2003; Butkauskas et al., 2012).

Received 29 September 2016 Accepted 22 September 2016

\section{References}

1. Aljanabi SM, Martinez I. Universal and rapid salt-extraction of high quality genomic DNA for PCR-based techniques. Nucl. Acids Res. 1997; 25: 4692-3.

2. Bregnballe T, Lynch J, Parz-Gollner R, Marion L, Volponi S, Paquet JY, David N Carss, van Eerden MR, editors. Breeding numbers of Great Cormorants Phalacrocorax carbo in the Western Palearctic, 2012-2013. IUCN-Wetlands International Cormorant Research Group Report. Scientific Report from DCE - Danish Centre for Environment and Energy, Aarhus University 2014; 99: 224.

3. Butkauskas D, Švažas S, Tubelyte V, Morkūnas J, Sruoga A, Boiko D, Paulauskas A, Stanevičius V, Baublys V. Coexistence and population genetic structure of the Whooper Swan Cygnus cygnus and Mute Swan Cygnus olor in the Eastern Baltic Region. Central European Journal of Biology. 2012; 7(5): 887-94.

4. Dagys M, Zarankaite J. Status of the breeding population of Great Cormorants in Lithuania in 2012. In: Bregnballe T, Lynch J, Parz-Gollner R, Marion L, Volponi S, Paquet JY, Carss DN, van Eerden $M R$, editors. Breeding numbers of Great Cormorants Phalacrocorax carbo in the Western Palearctic, 2012-2013. IUCN-Wetlands International Cormorant Research Group Report. Scientific report from DCE - Danish Centre for Environment and Energy, Aarhus University. 2014; 99: 140-2. 
5. De Nie HW. Changes in the inland fish populations in Europe in relation to the increase of the Cormorant Phalacrocorax carbo sinensis. Ardea. 1995; 83: 115-22.

6. Grishanov G, Chaika K, Nigmatullin I. Status of the breeding population of Great Cormorants in the Kaliningrad region in Russia in 2012. In: Bregnballe T, Lynch J, ParzGollner R, Marion L, Volponi S, Paquet JY, Carss DN, van Eerden MR, editors. Breeding numbers of Great Cormorants Phalacrocorax carbo in the Western Palearctic, 2012-2013. IUCN-Wetlands International Cormorant Research Group Report. Scientific report from DCE - Danish Centre for Environment and Energy, Aarhus University 2014; 99: 175-7.

7. Grishanov G, Romanov J. [Game fauna in Kaliningrad region of Russia.] Mishutkina Publishers, Kaliningrad, 2007; 201 p. Russian.

8. Goostrey A, Carss DN, Noble LR, Piertney SB. Population introgression and differentiation in the great cormorant Phalacrocorax carbo in Europe. Molecular Ecology. 1998; 7: 329-38.

9. Hagemeijer W., Blair M. The EBCC Atlas of European breeding birds: their distribution and abundance. London, T \& AD Poycer 1997; $903 \mathrm{p}$.

10. Lindell L, Mellin M, Musil M, Przybysz J, Zimmerman H. Status and population development of breeding cormorants Phalacrocorax carbo sinensis of the central European flyway. Ardea. 1995; 83: 81-92.

11. Marion L, Le Gentil J. Ecological segregation and population structuring of the Cormorant Phalacrocorax carbo in Europe, in relation to the recent introgression of continental and marine subspecies. Evolutionary Ecology. 2006; 20: 193-216.

12. Przybysz J, Engel J, Mellin M, Mrugasiewicz A, Przybysz A, Przybysz K. [A quantitative increase of the Cormorant (Phalacrocorax carbo sinensis Shaw \& Nodder) population in Poland]. J. Przegl. Zool 1988; 32: 71-81. Polish with English summary.
13. Reed D, Frankham R. Correlation between fitness and genetic diversity. Conservation Biology. $2003 ; 17: 230-7$.

14. Rozas J, Sánchez-Delbarrio JC, Messeguer X, Rozas R., DnaSP, DNA polymorphism analyses by the coalescent and other methods. Bioinformatics 2003; 19: 2496-7.

15. Švažas S, Chukalova N, Grishanov G, Pūtys Ž, Sruoga A, Butkauskas D, Raudonikis L, Prakas P. The role of Great Cormorant (Phalacrocorax carbo sinensis) for fish stock and dispersal of helminthes parasites in the Curonian Lagoon area. Veterinarija ir Zootechnika (Vet Med Zoot). 2011; 55(77).

16. Tamura K, Stecher G, Peterson D, Filipski A, Kumar S. MEGA6: Molecular Evolutionary Genetics Analysis Version 6.0. Mol Biol Evol. 2013; 30(12): 2725-9.

17. Thompson JD, Higgins DG, Gibson TJ. CLUSTAL W: improving the sensitivity of progressive multiple sequence alignment through sequence weighting, position-specific gap penalties and weight matrix choice. Nucleic Acids Res. 1994; 22(22): 4673-80.

18. Treinys R, Dementavičius D, Rumbutis $S$, Švažas S, Butkauskas D, Sruoga A, Dagys M. Settlement, habitat preference, reproduction, and genetic diversity in recovering the whitetailed eagle Haliaeetus albicilla population. Journal of Ornithology January. 2016; 157(1): 311-23.

19. Tubelytė V, Švažas S, Sruoga A, Butkauskas D, Paulauskas A, Baublys V, Viksne J, Grishanov G, Kozulin A. Genetic diversity of Tufted Ducks Aythya fuligula in Eastern Europe. Central European Journal of Biology. 2011; 6(6): 1044-53.

20. Van Eerden MR, Gregersen J. Long term changes in the northwest European population of Cormorants Phalacrocorax carbo sinensis. Ardea. 1995; 83: 61-78.

21. Winney BJ, Feare C, Parkin D. Preliminary results of a genetic investigation into the origin of the British inland Phalacrocorax carbo breeding colonies. Supplementi alle Ricerche di Biologia della Selvaggina. 1998; 26: 575-83. 
22. Winney BJ, Litton CD, Parkin D, Feare C. The subspecific origin of the inland breeding colonies of the cormorant Phalacrocorax carbo in Britain. Heredity. 2001; 86: 45-53.

23. Žydelis R, Gražulevičius G, Zarankaitė J, Mečionis R, Mačiulis M. Expansion of the Cormorant (Phalacrocorax carbo sinensis) population in western Lithuania. Acta Zoologica Lituanica. 2002; 12: 283-7.

\section{Dalius Butkauskas, Kristina Chaika, Saulius Švažas, Gennady Grishanov, Algimantas Paulauskas, Žilvinas Pūtys \\ DIDŽIŲJŲ KORMORANŲ PHALACROCORAX CARBO GENETINÉ IVAIROVE் RYTŲ BALTI- JOS REGIONE}

\section{Santrauka}

Spartus kontinentinio didžiųjų kormoranų porūšio Phalacrocorax carbo sinensis arealo plitimas Europoje pastebètas XX a. 8-ajame dešimtmetyje. Didžiųjų kormoranų genetinès įvairovès tyrimai Baltijos regione pagal molekulinius žymenis buvo inicijuoti siekiant atskleisti naujų perinčių didžiųjų kormoranų kolonijų, besikuriančių Rusijos Karaliaučiaus srityje ir Lietuvoje, formavimosi ypatumus. Perinčių individų pavyzdžiai molekuliniams tyrimams buvo renkami didžiųjų kormoranų perimvietėse ties Kuršių marių pietine pakrante
Karaliaučiaus srityje ir Drūkšių ežero pakrantèje Lietuvoje, o migruojančių individų - Birvètos ir Kaplių žuvininkystès tvenkiniuose Lietuvoje. Išsiaiškinus skirtingose teritorijose surinktų didžiųjų kormoranų mėginių mtDNR kontrolinio regiono fragmentų sekos kaitą ir palyginus sekas, nustatytas 21 skirtingas haplotipas. Didžiųjų kormoranų 8 haplotipai aptikti pirmą kartą, o 13 haplotipu jau anksčiau buvo aprašyti kitų tyrèjų. Haplotipų pasiskirstymas ir aptinkamumo dažnis tirtose imtyse buvo skirtingas. Remiantis 342 bp D-kilpos sekomis, išskirtomis šio darbo metu, taip pat pasitelkus skirtingiems haplotipams atstovaujančias sekas, kurių duomenys paskelbti GenBank duomenų bazeje, buvo sukurtas haplotipų tinklas. Naujai aprašyti haplotipai kartu su $P$. c. sinensis porūšiui priskiriamomis sekomis jame pasiskirste atskirai nuo P. c. carbo porūšio. Naujai aprašyti haplotipai priskirtini kelioms filogenetinèms linijoms ir galbūt atstovauja individams, kildinamiems iš skirtingų didžiųjų kormoranų perimviečių. Nustatyta genetine ịvairové, būdinga Rytų Baltijos regione perintiems didiesiems kormoranams, sąlygoja adaptacinị potencialą, užtikrinantị spartų šios populiacijos plitimą ir naujai besikuriančių perimviečių gyvybingumą Rytų Baltijos regione.

Raktažodžiai: mtDNA, D-kilpa, Phalacrocorax carbo sinensis, haplotipų ịvairovè, genetinè struktūra 